\title{
The Imaginative Ethnographer as Vagabond Bricoleur: Being Still, Being Quiet, Standing in Love and Paying Attention
}

\author{
An Interview with Magdalena Kazubowski-Houston and Virginie Magnat \\ D. Soyini Madison Northwestern University
}

\begin{abstract}
This interview discusses the infinity of stories as an endless reservoir of imagining new forms of meaning, feeling and embodiment of fieldwork data. Thinking of ethnographic analysis and experience as a collaborative process of performance and creative expression is an alternative to the prevailing textocentric documentation that demands both a political economy of contexts and an ethics of loving attention.
\end{abstract}

Keywords: textocentrism, co-performative witnessing, vagabond bricoleur, political economy of attention, embodiment, infinity of story

Résumé : Cette entrevue traite de l'infinité des histoires comme d'un réservoir sans fin pour imaginer de nouvelles formes de significations, de sentiments et de données de terrain incarnées. Concevoir l'analyse et l'expérience ethnographique comme un processus collaboratif de performance et d'expression créative offre une alternative à la documentation texto-centrée dominante et exige une économie politique des contextes autant qu'une éthique de l'attention aimante.

Mots-clés : incarnation (embodiment), témoignage co-performatif, bricolage, collaboration, commun

\begin{abstract}
Note from the editors: This interview took place via video
\end{abstract} conference on 16 October 2015.

D. Soyini Madison: I would like to think of the choice to conduct this interview as a form of imaginative ethnography. The decision to change the format of a written essay to more of an engagement with the two of you where we are in dialogue - sharing time and virtual space together while listening together inside our shared vocal responses - seems more of a move toward an embodied and enlivening exchange. I am not the sole author of a textual object, distanced from you. I love the idea that we're generating this exchange together.

Magdalena Kazubowski-Houston: Yes, it's about sharing the space that becomes the impulse for the conversation, for ideas that might not necessarily materialise in those ways through a written form.

D.S.M.: I would describe imaginative ethnography as constituting four reciprocal dynamics. The first dynamic comes from the fact that stories are infinite. We may run out of water, air, food and natural resources if we continue to abuse our planet; we may run out of money and all those material things that we as humans sometimes overvalue, but as long as there are humans (and sentient beings), we will never be at a loss for stories. We don't have enough time and space to engage the abundance of stories that are held within each human life on this planet, nor can we remember all the stories that are embodied and experienced within our own nervous system and musculatures. So, imaginative ethnography might begin with the truth of the infinity of stories - told and yet to be told, imagined and lived. The second dynamic is linked to the countless forms that hold the story. Beyond the "beginning, middle and end" narrative structure that in itself can capture countless forms, there are presentations and representations, modes and manners of storytelling that exceed narrative. The excess of story is grounded in the double excess of how these stories are presented, how we witness them and the forms they take. I find a story in dress and adornment, in gardens

The Imaginative Ethnographer as Vagabond Bricoleur / 457 
and paintings, in dance and imagery and so forth. All these modes of expression constitute and express a story through the hearts and minds of their creators in alterity to words or narrative structures. The third dynamic involves an ethics of attention, which entails being still, being quiet, to focus and attend to that which is present before you and that surrounds you in the here and now of the field. We need to be still, we need to keep quiet, we need to stand in love, and we need to pay attention to fully attend to the feelings, senses, meanings and stories that emanate from the sights, sounds and motion of engaged and imaginative fieldwork. Let me provide the example of jazz singer Dianne Reeves performing "Testify" on her album Bridges. This song beautifully underscores what it means to live inside a moment, to honour the immense fullness of the present. The lyrics "Be still, stand in love, and pay attention" are what I hope to be and do in my ethnographic work. We can strive for attention to be fully present - not only for the sake of a more accurate and thickly described ethnography but for the sake of ethics. I cannot be alert unless I am paying deep attention, and when I am still, when I stand in an ethics of love, I become alert to the politics of collective being and survival. There are those moments where we are lovingly still and quietly attending to the field site as it opens itself to us - to show and tell us what is there - beyond what we thought or even imagined. In the simple act of being still and present, there is the alchemy from which discovery emerges, when we are suddenly attending to an ethnographic present that we might not have ever seen, understood or even thought possible.

Being still, standing in love and paying attention is not only an ethical act; it is also a political one, since ethics are inseparable from politics. In this instance, ethics and politics conjoin in the claim that "I am here and I am so deeply and radically listening and attending to this moment in all its profundity and immense excess because it is my responsibility to do so." I am here with you and at the same time understanding that, somehow, I am a part of this because, yes, we are all made of the same star-stuff. I may be uncomfortable. I may be disturbed. I may not even like the people here. I may not even like the person that I'm interviewing. I may politically and ideologically object to what is going around me, but I still have an attachment and a commitment in some way to the life, the lives, the meaning making and the actions that I will record, represent, make more public and carry forth beyond the parameters of this location, and my doing so doesn't negate the inner core of who I am. Maybe it's not so much about this particular space, but the fact that I am here, in this particular location, and
I have a responsibility - to someone, perhaps everyone, somewhere, perhaps everywhere - to acknowledge for good, purposeful and consequential reasons that should matter on a grand scale why I am here, what I learned and felt here, why all these stories and strivings for loving attention were worthwhile.

Beyond the surplus, the excess of endless stories that are cast in the double layering of infinite forms, when through an ethics of attention we are able to listen to, witness and co-perform these stories, we come to the fourth dynamic: the inventive and embodied vagabond bricoleur. Given all the stimulus in the field, how do your senses land on any one story, feeling, image, sound or action? Imaginative ethnography doesn't erase the body, and being an inventive bricoleur means that we understand that we are doing this through bodies. When we give credit to the power of the body, what does that add? We then realise that the actions, the gestures that our bodies create are part of social systems that have been transmitted to us - borrowed, replicated, mimicked and transmitted through a lineage and history of other bodies formed by political, economic, social, geographic and environmental factors. The way I speak to you now, and even the way I move and gesture - the way I may chant and act up at a protest rally, the way my body engages with friends - are all part of an abundance of embodied techniques that I have learned from the communities I inhabit. They are not only mine. Just like language, which we learn socially, we learn our body techniques through the history and politics of socialisation. To acknowledge the body also means acknowledging that emotion and affect - how we feel and how we sense does not happen only in our heads and in discourse, but through the sensing, feeling, breathing body. This is why we can no longer think of mind, ideas and theories without bodies. What happens in our bodies indicates who we are, who we engage with. Social economic forces form and guide what we do with our bodies, where they roam, how we care for them, and we are attached to other bodies that look like ours for protection, survival, habit or comfort. The notion of embodiment can also help us to understand that our theoretical conceptualisations can become much less relevant, effective and beautiful to us without bodies to bear witness to them, enliven them and make them manifest. The fourth dynamic of the vagabond bricoleur enables us to gather and make anew the endless layerings within the reciprocal dynamics I have outlined. The vagabond bricoleur is the imaginative ethnographer who is on the move to carry, with quiet attention and love, all these layerings upon layerings.

Virginie Magnat: I feel that your words strongly resonate with those of Cree scholar Shawn Wilson, the 
author of Research is Ceremony, who recently gave a talk at UBC's Okanagan campus. There seems to be an overlap between what you are saying about the ethics of research and Wilson's provocative assertion that if research doesn't change you then it hasn't worked. For the Indigenous graduate students who attended his talk, however, it can be challenging to speak about how research is ceremony, which is the title of Wilson's influential book on Indigenous research methodologies. So I sense a possible connection between this perspective and your discussion of the ethics of love that really goes beyond the world of the academy, which is very individualistic and very much about individual success and self-promotion.

M.K.-H.: I am really interested in your comments about the abundance of stories, the idea that there are plenty of stories to share. I am wondering whether you could speak about the work you have done with marginalised people who are facing everyday violence and oppression. Within this context, how do you think imaginative ethnographers can position themselves when these people fear that their stories might be stolen? I'm thinking about my work with Romani people in Poland, where there is always this sort of awareness that what I'm hearing as an ethnographer is not what I should be hearing, because those who tell stories in that context, and those who listen, don't always have the same power, access to resources and authority to speak. How can the imaginative ethnographer address such challenges in those specific ethnographic contexts?

D.S.M.: In the contexts you outlined, stories absolutely can be stolen. I think that when stories are stolen, this taking occurs because ethnographers don't think they have any stories to tell, yet by stealing stories they (knowingly or unknowingly) dishonour the storyteller. This is not paying attention; this is not standing in love; this is not ethical. This could be due to the ethnographer's incapacity to notice and embrace the multitudes of stories in circulation. Perhaps it is laziness or bad training. When you are covertly taking someone else's story, and giving yourself credit for it, this is something different. We're talking about the ethnographic project where you are involved in a life history and you rework that life creatively and imaginatively, because it may be more interesting to you, or more compelling, told another way. Perhaps you have stolen the emotion, the affect, the articulation away from your interlocutor to satisfy your particular audience. Or, if your intentions are not that malevolent, perhaps you are taking over a story innocently because in the domain of the sensory and the imaginative, you feel that you have license to interpret the narrative, but, in the end, your interlocutors no longer recognise their own story.
M.K.-H.: Yes, yes. Absolutely. This is my concern.

D.S.M.: I think that it is our responsibility to provide a nuts-and-bolts response - concrete tools that can help us to understand when we're overstepping our bounds. For instance, the notions of co-performative witnessing and collaboration remind us that we are telling, presenting, making a story together, with our interlocutors, and there are checks and balances that must be in place. While it doesn't necessarily or always eradicate the problem, it can serve as an effective ethical preventive measure. We must also keep in mind that we work in the academy and, most often, wield a certain kind of power. This should make us even more keenly aware of our positionalities, our influence and the deep and abiding consequences of arrogant and empirical ownership. So, what does this kind of collaboration and this dialogue entail? Because we often have more power, we must give more blood, sweat and tears to make what we are interpreting and translating also transparent and intelligible to our interlocutors.

I usually ask my interlocutors to read what I've written, but I must specify that it is not always the case in every instance. Sometimes I do not have interlocutors read what I have written because they may not know my audience, or my interpretive community, or my home space. The kind of interventionist and advocacy work, the problems and obstacles of that work, may be foreign or outside the lifeworlds and experience of my interlocutors. I may not share this for strategic reasons, but I think it remains vital that we still inform, explain, interpret our strategy, language and contexts so our interlocutors are clear about where their stories are being told and to whom and where. One example from my fieldwork was when I did the performance "Is It a Human Being or Girl?" and I implicated US foreign policy as a problem in the defence of human rights by making the connection between US policy, poverty and human rights. Some of my interlocutors felt I should not implicate the US and were against connections between poverty, trade, policy and human rights in Africa. Now, if I listened to them I would be doing a show about how bad Africans are treating each other. Of course, many other local activists felt this connection was of urgent importance. But certain interlocutors thought it rude, insulting and irrelevant to be as critical as I was of my home country. So, what do you do in a case like that? I knew there were many other local, Ghanaian activists who understood both sides of the argument that I shared my work with, and who were interlocutors with high stakes and deep commitments to human rights. I took my lead from them. So I had to seek out folks who had a stake in the issue but who also knew both sides. I can't always trust myself to think that 
some interlocutors are wrong or uninformed on issues, and that I can proceed with what I think is right or best for them. This is why it is important to seek more voices, a deeper, broader understanding. You will discover they were right all along, or you were correct in your position that was against theirs. What matters is that either way, it is local knowledge and the lives/experiences in the field that guide your choices.

In addition to the recommendations that you collaborate with interlocutors and seek out other stakeholders, beyond your collaborators, who are invested in the struggle and politics on the ground, is yet a third consideration: we need to look toward our own intellectual traditions and theoretical foundations. I do go back and read theory. I go back to those folks who may not be ethnographers but are deeply invested in questions of poverty, justice and freedom. I also turn to my colleagues - some do ethnographic research, but many do not. I learn so much from them about the precision, clarity and implications of my work.

M.K.-H.: Thank you. My second question relates to your inspiring discussion of imaginative ethnography. It's about stopping and listening, instead of speaking. Being familiar with your work - for example, Acts of Activism, a book I teach in my graduate classes - I feel that there is such richness of detail and complexity in your writing and that it is definitely a huge investment in imaginative ethnography. So, I was wondering if you could address the challenges of doing this imaginative ethnographic work that requires this kind of arrest and attentiveness, especially in the context of being a researcher positioned in a neoliberal economy, where production and productivity are privileged over this kind of careful research. There is an ongoing conversation among anthropologists about how difficult it is to do fieldwork in the ways it was done before. Of course, there were problems with these kinds of approaches to fieldwork, but people spent their entire lives doing research and writing ethnography. Today, there is this push to increase research productivity in a shorter period of time, and, as you stated, there has to be more to this work than simply wanting to write to become known. There has to be something inside of us that drives our work. So, what do you think the challenges of doing imaginative ethnography are today?

D.S.M.: Embedded in description is beauty and politics that will move people to want to believe not only what you're saying but to envision being there themselves. So, I think that as teachers of this method, particularly as it pertains to descriptive language, we need pedagogies that convey, through poetry and prose, and through embodied exercises and practice what it means to honour thick description. In my performance ethnography seminar, the first part of the class is a "practicum" where students must leave the classroom for about 20-25 minutes to conduct a sensory exercise in a particular location. They don't have to take any notes, but their task is to listen to the sounds around them. However, it's not enough to tell them to listen to the sounds around them. So, I ask them to listen to the sounds that have a particular rhythm, as well as a distinct kind of repetition. Are there voices that overshadow those sounds or interrupt them? What might be the cacophony of voices, machinery and/or nature that might possibly impinge upon the particular soundscape? They must be given detailed instructions, otherwise they won't know how to deeply listen. We know, as ethnographers, that we are also poets. We listen to the intricacies, the comparisons and contrasts of sounds, their tones, their layers, all of the surprises and different manifestations that constitute them. So, I ask students to work outside of the classroom to help them understand that the ethnographic enterprise always entails the body going out and engaging the world through its senses. Ethnographers visit locations and see, hear, smell, taste, feel what is there. We cannot limit ourselves to reading, writing and talking about locations; we must enter through our senses. I think that being committed to training imaginative ethnographers, really striving to be a good teacher, and feeling the weight of that responsibility is another way of dealing with lazy, quick, insensitive, exploitive, imperialist and colonialist tendencies that rear their ugly heads from time to time in our qualitative or ethnographic methods and analysis. I also think that it is important to make our criticisms public. I don't mean that we need to be cruel, but to be public in the questions we ask of these works. Maybe public is not the right word, but we need to be open in our conversations by consistently asking each other what ethics looks like, what caring and accountability look like. None of us are doing this alone. We have comrades, we have colleagues, we are in this work together, and that's very powerful. We have alliances, and our alliances must be generously critical, so we are constantly learning how to do our work well. It also means that we hold each other accountable. This is what equips us to create and to honour detail. We as teachers and students should be taught and inspired, through ongoing critical and open forums, and anything short of this is not who we want to be or the work we want to do.

I read a lot of creative non-fiction and a lot of novels, and I think that it is really important to turn a phrase, to honour the metaphor, to use descriptive language - to write about a certain kind of chair belonging to a figure of authority and not just name it as a chair, but describe 
the texture of its fabric, where this chair is positioned in the room, how the light shines on it. This is not just silly superfluous description, but it conveys why that particular chair is special and the labour of making that chair, and where that labour comes from, and the class systems in place in this particular idea of royalty that is being contested by local activists. So, the role of descriptions is to make us understand the importance of that object and the objects around it, as well as the social life and political implications of these objects. I believe in the beauty of detail, of metaphor and symbol, when doing descriptive work.

V.M.: I wonder about the importance of the arts as an area that has been influential in creating those techniques, especially performance practice and training. If we are working across performance studies, critical ethnography and imaginative ethnography, how do we integrate performance practice, which is such a powerful tool? I'm thinking of how Victor Turner invited anthropology and theatre students to work together. While it is necessary to look critically at these early experiments, we have not continued to explore such possibilities as fully as we might. Performance can train us to be still and pay attention, to be with others in the same space, and to feel ethically responsible for our community in a deeper way. I am thinking of what you described in Acts of Activism, the parable songs that the Ghanaian community was singing in response to activists who were speaking out about hope for the future, about people coming together, and for me this brings up Victor Turner's notion of communitas, which can be problematic for various reasons; yet perhaps there is something there that we need to further explore.

D.S.M.: Sitting as an audience member before the virtuosic performer arrests my attention, makes me feel and connect emotionally, as well as intellectually, while at the same time being emotionally disturbed by what I see and what is going on in the performance. As a tactic, performance is a very powerful way to hold one's attention to certain urgent realities in the world. In performance, I employ the imaginary, those descriptors in the field that I cannot carry with me but that I carry into performance. I carry them through representative objects or language or lighting or movement on stage. We know that when we see a film or listen to music or engage with performance of any kind, or even a painting, we are carried cognitively, and through our musculature and nervous system, into that world for that very eventful moment. It seduces us into its presence. Performance becomes the closest means of being there, being imaginatively transported, as well as feeling the rhetorical power of a place or situation. I want audiences to both and alternatively empathise and disengage, to feel pleasure and to be disturbed. It is a heightened, framed moment. Everyday quotidian moments in the field are both ordinary and extraordinary, and in performance, we deeply recognise them because they are not only heightened moments that act as a punctum, a kind of time out of time that extends itself in a particular moment that makes it special, but because we also know that something is going on there that extends the meaning of that moment. There is something that is commented upon, even if it is not verbally explicit, but that is revealed in action. There is something that can be gleaned about that particular moment unfolding in that particular way, that opens up to us, to what we can understand more deeply, akin to an ethnographic moment that we may not otherwise notice. It also helps us to understand that something is happening in someone's body, in their sense-feeling-being that emerges, and we are able to glimpse through the performance what that person may have been internally thinking - who they are and why they do what they do, or what they might have been.

To recognise those moments in the field within a staged performance - the small gesture of a handshake promises to open up the response, "Oh! That handshake is an expression of a particular place, in a particular time, between particular people." We realise this is a moment with meaning and feeling within and across the bounds of a relationship, culture and history. These small signifying performative gestures, actions and movements are filled with consequences and implications.

In my book, I write about the activist Kwesi Pratt and a protest march that becomes a confrontation with the police. All these protestors are marching in the street while singing and chanting. This form of protest that uses songs and chants is practised all over the world. It is a universal performative. So what's different about this one? Well, every single march happens at a particular place in time, with different people, for different reasons, and every one of them is a different story. So, while that particular moment where the marchers were almost shot by the police may have appeared to some as just another news item, if we interpret it as a performance, we can ask why the police did not shoot. What changes and transformations occurred when these particular protestors sang, marched and sweated together? All these individual subjectivities were also one organism under a commons of protection, for each other. What does that give off? I am interested in these small gestures that are embodied with and impacted by so many layers of intent, history and consequences. And to write about them and to represent them is to honour them. In my work, I hear over and over again, "Oh, be careful"; or "You 
know there's so much violence"; or "Is it really as bad as they say it is?"; or "Do people wear shoes?" Too many people don't have a clue about the courageous and the very brave and brilliant local activists and human rights defenders. These are African people who are making a monumental difference in the protection of human rights across their communities and nations, literally saving lives through the tactics of storytelling and performance.

It is not easy for them - change rarely happens instantaneously - but we should know more about their work. Local activists make change all over the world in places where we believe there is only devastation. There's always the courage and genius of local people, on the ground, making miracles happen in their own country toward rights and justice; yet it seems that most of us are more interested in the abuses that are waged than in the local people who are intervening on those abuses. It's a shame, because this is where the real solutions, the real relevance and the real answers can be found - in the stories of these local activists.

V.M.: For me, this brings up Jill Dolan's notion of utopian performative, not within the theatre but in the real-life events you are describing, when communities come together in such powerful ways. Dolan employs the words hope and love, which have not been very popular in postmodern theory because of their problematic connection to affect. In your book, you state that we have become quite suspicious, for justifiable reasons, of affect, embodiment and the notion of communitas. You stress that you are aware that people need to be absorbed in this type of experience while simultaneously thinking critically and reflectively about it, because the potential dangers of celebrating embodiment or community unreflexively have been made quite clear by performance studies scholars. Yet, if we are talking about performance, how can we avoid speaking about embodiment, affect and the powerful experience of community-driven activism that you evoke? I think that we need to value the ability to convey this through ethnographic writing, and when I read your book, I feel viscerally engaged in the movements of solidarity you describe. To me, this is the function of imaginative ethnography, because I cannot be there with you, and because you are writing about the past, and yet you invite me to enter into your embodied experience.

D.S.M.: Yes, it is necessary to imagine how to describe, how to present what is absolutely unique and different, in a unique and different way. We know that what is unique and different might look very ordinary, and it may look like previous similar events, but if we do imaginative work, we become excavators of what is extra-ordinary about a particular event. We must dig deep; we must understand the context, the consequences; we must pick it apart and ask ourselves what is going on here that causes something to change, to be worthwhile, to mean something. And because we must carry it forward, beyond our own reckoning, into translation, we must put it all together and mark what is profound about it, so that it makes sense, so that it is clear.

V.M.: It seems to me that it is important to be able to understand the power of people singing and chanting together, and how this performance of community creates change. If we look back to the Civil Rights Movement, we know this was a moment in time when things changed, and we know that people made these changes happen somehow and that this process was incremental, but historically there was a turning point, and something powerful took place. Understanding how this was possible can perhaps help us to be more actively engaged in the present and might enable us to imagine the future based on all of the performances that took place before us.

D.S.M.: Right, and I think that is what Jill is thinking about when she writes about the utopian.

And, you're right, there's been a lot of criticism about the utopian and the notion of communitas, on the grounds that these ideas are too optimistic, too ambiguous, too conservative and too bourgeois. And maybe they are, at times, in the ways in which they have been employed, but what is the alternative? What is the alternative to resistance? What is the alternative to believing that we have a responsibility to our planet and to our interlocutors, that we have a responsibility because we have been given this opportunity to spend some time with them and then we can return to our office and write - I mean, are we not supposed to be held accountable, are we not expected to make a contribution, to make all this really matter? What we can offer is an understanding that in every circle of resistance and progressive politics, people are making something beautiful. Even if it's the way a mother holds her baby, or how someone touches another person's hand to console them, even in the deepest ways we are suffering, there is this will to survive, and how it is manifested, how it is enacted, takes on so many different forms and appearances. I think paying deep attention to those forms, those resistances and survival gestures will negate pessimism, it will negate defeatism. I've heard the harangue about how bad things are and how nothing can be changed, or how awful people are and how we should not embrace the utopian or hope because it is useless, false consciousness. When we negate the utopian and hope, we are also negating those small gestures of survival that are and can become mighty and abundant. 
V.M.: Shawn Wilson spoke about something similar in relation to decolonising the academy. He observed that, yes, we can be anti-racist, but it's like an antibiotic: sometimes we're so sick that we have to take it, but we can't stop at that; we have to go further. He talked about love and hope for Indigenous people in Canada and stressed that it has finally become possible for Indigenous communities to start thinking about that. They can now work toward that, rather than just survival, and decolonising, which of course is an ongoing project, although he pointed out that, from an Indigenous perspective, that's not good enough. This seems to suggest that critical thinking can help us to resist, but for change to occur we also need to think about, or perhaps imagine, what we are looking forward to achieving together.

D.S.M.: Right, because isn't the imagination fuelled by the desire to be expressed? And when we talk about imaginative ethnography, are we not imagining that which is beyond what we've already experienced, beyond what is taken for granted, some element that is just now born? Imaginative ethnography is actively and consciously re-creating the new. And, because it is actively assembling that which has never been told, or said, or seen, or experienced before in this particular way, it means that we can never run out of these imaginings. There is no scarcity. We can believe we will never run out of stories, like we will never run out of the distinctiveness of a human face or human experiences. As long as we nurture our planet and living organisms, our imaginations, just like stories, experience and the human face, will keep multiplying anew, differently each time at each rebirth.

M.K.-H.: I am wondering whether you could share with us your reflections about the work you do with performance as an imaginative strategy or technique in ethnographic fieldwork. A lot has been said and written about performance as a form of ethnographic representation, but there seems to be more of a focus on performance as a form of representation than on performance as the very technique of doing fieldwork, of interacting with people. You talked so beautifully about the importance of connecting to people as other human beings with their own stories. How do you see performance factoring into this? What are some possible future directions for thinking about how performance can be used as a strategy and technique of fieldwork?

D.S.M.: There are various sites of performance. There are the everyday performances occurring in the field and the staged performances that enact or represent the quotidian performances from the field. There is also the event of the oral history interview that can be framed as a performance, as well as those performances told to us and revealed in the content of the telling. There are also those instances upon our return from the field where we reperform for colleagues, family and friends those unforgettable and impressionable moments from our fieldwork that we must share with them. There are so many layers and layers of performance. When we are talking about the everyday performances in the fabric of fieldwork, those are locatable and often framed because those are the moments that give off the interpretive context of what happened that might not otherwise be understood or known by an outsider. For example, we might not understand the kind of hierarchies in the marketplace, the tensions among market women or the secrets of the marketplace, in terms of how the police discipline and punish market women and why they must set up their kiosks in certain areas. If you are merely passing by, if you are an outsider, you can't necessarily interpret the protocols, behaviours or codes because they are understood locally by Indigenous people. The only way to grasp the dynamics and meanings would be through interviews. But maybe even within the interview nothing is revealed. So, from the performance perspective, if you have spent time with deep listening and attention, you have learned to understand how people and objects are placed in particular spaces; you see a pattern of performance within specific roles, behaviours and identities. You have co-performed symbolic, and gestural, rituals - repeated daily greetings and ceremonies. You have observed and become a trusted listener to oral history performances that reveal who is in charge and why they move in a certain way or why they are sequestered in this other way. I may choose to represent that performance on stage with and for and by the very market women themselves. They are performing themselves without necessarily giving credit to themselves as performing in the first place until they see themselves staged. So, technically, how does this reperformance work when it is publicly staged and framed as a performance? What does that mean and do for the very people that it is about? They now see themselves in a way that allows them to observe the dynamics of their actions and the consequences of those actions, which they would not otherwise know. They may have no time to be reflective about the consequences, but in performance they do. This happened with a local performance directed by theatre majors at the University of Ghana in Accra with market women on opposite political campaigns during elections in Ghana in the 1990s. These young Ghanaian students put on the performance before the market women about market women and their antics and hostile behaviours during elections. The women laughed at themselves and with each other. It got them talking with 
good humour and self-awareness. This was a success, but not all our efforts are successful. This performance work is very, very hard work, and sometimes we fail. However, this is one example of making a staged performance for a local audience about a local problem. I don't mean to say these performances are a cure-all. They are not, and they are very hard work when done with respect for artistry, craft, beauty, as well as local knowledge and ethical politics.

When performances reach the third level of being transportable and moving to a different audience, for example, an American audience, you must keep in mind that many audience members have no experience with people in other parts of the world beyond the too-often stereotypical notions conveyed by popular culture. They don't know that certain other people in the world exist in this way. The labour of ethnographic performance is to show that certain other people not only exist, but they have opinions, they have agency, and they have futures. And what I have found to be true is that these audiences may not know much about the interlocutors in the field, but the interlocutors in the field know about them, their country, their way of life. These citizens of the Global South have a worldliness and international intelligence many in the Global North do not realise. Okay, we may not know them, but they know us. Many know the policies out of which we, and they, are governed and the inequities of these policies, and they are telling us about ourselves and about our nation. Performance allows us to enact those sensibilities and knowledges from the field, enact those identities on stage through an imaginative rubric that is also deeply true, so we can have some kind of access to that world and that world's notions of itself, its notions of us, and its hopes, actions, activism and tactics for alternative ways of being. So, it becomes an embodied visceral kind of experience, and it provides an opportunity for empathy. It allows you to imagine what it would be like to be there and to be them, and it allows them to think about who you are as you are watching them.

V.M.: I am wondering whether you could speak about the fetishising of the written archive in the academy, a critique of textocentrism developed by Dwight Conquergood to challenge ethnographers to bring back embodied ways of knowing into academic discourse in order to engage people on a different level. I am thinking about our graduate students who are trying to understand what is possible in terms of methodology, and also about the role of imaginative ethnography when it comes to imagining creative methodological approaches. Of course, we know that the written archive and publications are not going away, but we need to explore alternative ways of doing research that are valuable on their own terms. Conquergood was clear about not taking a stance against texts and publishing when making this critique, but asserting instead that producing texts is not sufficient and that other perspectives are shut out by the hegemony of textocentrism, which he indicted as a form of cultural imperialism. There is something political about ushering in performance, embodiment and affect through the voices and experiences of people who might not be able to have access to our scholarship, or as you were saying, who might not be able to be our primary audience, but whose lives and experiences we are representing in our scholarship. So, this is a matter of accountability that must be foregrounded in our own research and teaching.

D.S.M.: Absolutely. I have found that many students seem to be unsettled by this idea of unravelling the notion that the text is supreme. It is as if they didn't know where to go with that, particularly those who are new to performance. In the academy, we know everything is about the text: you have to read the text, you have to make sure you do a close reading of the text, and then you come into the seminar having read the text, and you have to talk about the text, because reading and talking about the text also leads to you to respond by making a text, and then this making a text creates the steps to making an even bigger text, which is the dissertation. We are both enraptured and imprisoned by the text. And, you're right, Conquergood is absolutely not saying do away with the text. But this idea that the text does not reign supreme and that there are other ways of entering and producing knowledge is challenging to students because when the text disappears, are they being asked to do something with their body? Are they being asked to be seen? They'd much rather sit down from the neck up and write and embrace the text than have to get up off their chair and be vulnerable in that way. So, yes, the point I am making here is that I want to give credit to the text through performance and performance through the text. I always understand the performance more and deeply because writing helps me get at the implications and meaningful abstractions to then dig into the consequences. I strongly believe that writing requires you to think through ideas and concepts to assign phrases and language an intelligibility so that you can come to yet another reckoning with the performance. So, I absolutely need the text to value the embodiment of performance even more. But having said that, when I perform a written text, I become simultaneously more emotionally and more conceptually invested through the pulse and experiential archive of memory with my whole body that conjoins text in both my bones and brain. So, it is about this reciprocal relationship. There is a 360 -degree circle 
of how knowledge is produced and felt and represented through text and embodiment working together. It is a very dynamic process in the classroom when students read a text and talk about it and then choose phrases from that text and make body symbols, scenes, characters, abstraction, improvisation. How can they learn more deeply, or how can their learning be more heartfelt? And then to go back and write about that whole experience.

V.M.: Thank you for that.

M.K.-H.: I have one more question. We have been talking about the imaginative possibilities that ethnography takes on through fiction, storytelling and performance, but I am wondering what you think are the potential pitfalls or dangers of ethnographers engaging with the more creative arts-based practices? Is there a risk of aestheticising and fetishising our interlocutors' experiences? I am interested in your perspective on this because these questions have been of great concern to me, especially as I am grappling with doing this kind of work in a marginalised community with people who experience racism and suffering as part and parcel of their daily lives.

D.S.M.: Yes, there is a risk of aestheticising ethnographic work to the point that it becomes more about the strange and exotic, or the precious and noble, or the pitiful and tragic - fetishising on one end and demeaning on the other. It is challenging to delve into the complexity, nuance and vast economies of ethnographic experience. I don't think most artists and performers intend to stereotype, be melodramatic, go for the big laugh or indulge in solipsism and navel-gazing, even when accused of doing so. The other problem that is discussed in the literature is the notion of fixing the Other in time. Interlocutors have no past time or future time but are fixed in the forever time of our fieldwork. These are all the pitfalls and challenges.

We do need to be concerned about artistry. We are writers, artists, performers; therefore craft, technique, aesthetics and beauty are absolutely crucial, or else who would want to listen or watch our work, and how could it inform or inspire? But when folks were overauthenticating a narrow view of positivist and structuralist ethnography and downgrading imaginative and interpretive work, the positivists fell into the pitfall of absolutes, pure objectivity, ultimate truths. So, on the one hand, the criticism that what we do is too artsy-fartsy, flaky and unscientific, and does not represent authentic reality is a problematic and dishonest charge. On the other hand, it has already been proven that realities are not always immutable and fixed, objectivity is relative, and, most importantly, to ignore the profound realms of embodiment is simply bad training and misguided. I think we need to consider the tensions between these opposing ends and take lessons from both, but with our eye on the prize of our imagination. We do need to be concerned about evidence, comprehend actualities and tend to the materiality of facts. We should ask ourselves how we justify a particular aesthetic frame. Is the imaginary self-serving and gratuitous, enabling us to forget about data? The questions to ask, as we try as best we can to avoid these pitfalls, are "So what?"; "Who does our work serve?"; and "How does our work tell the story so we can get inside our translations in a deeper, more beautiful, more truthful and more connected way?"

V.M.: This has been a highly stimulating exchange, D. Soyini, and we would like to thank you so much for accepting our invitation and for engaging with a wide range of open-ended questions, which are all closely related to our thematic section. You have given us a lot to think about for our introduction, as well as many points of entry into the topics covered by each contribution, and we are very grateful to you for generously sharing with us and our readers your perspective on imaginative ethnography.

M.K.-H.: Yes, thank you very much!

D.S.M.: You are so welcome.

\section{Soyini Madison, Department of Performance} Studies, African Studies, Anthropology, Northwestern University, 70 Arts Circle Drive, Evanston, IL. Email: dsmadison@northwestern.edu.

\section{References}

Collins, Jane L., Micaela di Leonardo, and Brett Williams. 2008. New Landscapes of Inequality: Neoliberalism and the Erosion of Democracy in America. Sante Fe, NM: SAR.

Conquergood, Dwight. 2002. "Performance Studies: Interventions and Radical Research." TDR: The Drama Review 46(2): 145-156. https://doi. org/10.1162/105420402320980550.

. 2005. "Rethinking Ethnography: Towards a Critical Cultural Politics." In The Sage Handbook of Performance Studies, ed. D.S. Madison and J. Hamera, 351-365. Thousand Oaks, CA: Sage.

Davies, Charlotte Aull. 1999. Reflexive Ethnography. London: Routledge.

Deleuze, Gilles, and Guattari, Félix. 1987. A Thousand Plateaus: Capitalism and Schizophrenia, translated by Brian Massumi. Minneapolis: University of Minnesota Press.

Denzin, Norman K. 2010. The Qualitative Manifesto: A Call to Arms. Walnut Creek, CA: Left Coast.

Dolan, Jill. 2005. Utopia in Performance: Finding Hope at the Theater. Ann Arbor: University of Michigan Press. 
Hall, Stuart (ed). 1997. Representation: Cultural Representation and Signifying Practices. London: Sage. Hamera, Judith. 2006. Opening Acts: Performance in/as Communication and Cultural Studies. Thousand Oaks, CA: Sage.

2007. Dancing Communities: Performance,

Difference and Connection in the Global City. New York: Palgrave.

Johnson, E. Patrick. 2008. Sweet Tea: Black Gay Men of the South - An Oral History. Chapel Hill: University of North Carolina Press.

Madison, D. Soyini. 2005. Critical Ethnography: Methods, Ethics and Performance. Thousand Oaks, CA: Sage. 2006. "The Dialogic Performative in Critical Ethnography." Text and Performance Quarterly 26(4): 320-324. https://doi.org/10.1080/10462930600828675. . 2010. Acts of Activism: Human Rights as Radical Performance. Cambridge: Cambridge University Press.

Muñoz, José Esteban. 2006. "Stages: Queers, Punks, and the Utopian Performative." In The Sage Handbook of Performance Studies, ed. D.S. Madison and J. Hamera, 9-20. Thousand Oaks, CA: Sage.
Pelias, Ronald J. 2004. A Methodology of the Heart: Evoking Academic and Daily Life. New York: AltaMira.

Pollock, Della. 2007. “The Performative 'I." Cultural Studies $\leftrightarrow$ Critical Methodologies 7(3): 239-255. https://doi.org/10.1177/1532708606288649.

Reed-Danahay, Deborah. 1997. Auto/Ethnography: Rewriting the Self and the Social. New York: Berg.

Rivera-Servera, Ramon. 2013. Performing Queer Latinidad: Dance, Sexuality, Politics. Ann Arbor: University of Michigan Press.

Spry, Tami. 2001. "Performing Autoethnography: An Embodied Methodological Praxis." Qualitative Inquiry 7(6): 706-732. https://doi.org/10.1177/107780040100700605. . 2006. "A 'Performative-I' Copresence: Embodying the Ethnographic Turn in Performance and the Performance Turn in Ethnography." Text and Performance Quarterly 26(4): 339-346. https://doi. org/10.1080/10462930600828790.

Warren, John T. 2006. "Introduction: Performance Ethnography: A TPQ Symposium.” Text and Performance Quarterly 26(4): 317-319. https://doi. org/10.1080/10462930600828667. 